\title{
APLIKASI TOEFL PREPARATION BERBASIS IBT (INTERNET BASED TEST)
}

\author{
Bobby Putradana Rizky ${ }^{1}$, Atiqah Nurul Asri ${ }^{2}$, Deddy Kusbianto Purwoko Aji ${ }^{3}$ \\ ${ }^{1,2,3}$ Program Studi Teknik Informatika, Jurusan Teknik Elektro, Politeknik Negeri Malang \\ ㅎobbyputradana@gmail.com, ㄹatiqah.na@gmail.com, ${ }^{3}$ deddy_kusbianto@polinema.ac.id
}

\begin{abstract}
Abstrak
Perkembangan teknologi internet sangat pesat terutama web. Selain berfungsi sebagai media informasi, web juga dapat dijadikan sebagai media pembelajaran misalnya pembelajaran Test Of English as Foreign Language (TOEFL). Tes tersebut merupakan sebuah tes yang mengukur kemampuan bahasa Inggris seseorang. Pada aplikasi ini digunakan jenis TOEFL $i B T$ yaitu TOEFL yang berbasis internet. Tes tersebut terdiri dari empat sesi yaitu Listening, Writing, Reading, dan Speaking. Jenis ujian pun dibagi menjadi dua bagian yaitu Individual Test dan Integrated Test. Aplikasi ini menyediakan sebuah simulasi tes TOEFL iBT layaknya seperti tes yang akan dihadapi dan dapat membantu para mahasiswa untuk melakukan persiapan ujian TOEFL $i B T$ dengan mengerjakan soal-soal yang ada pada aplikasi secara mandiri.
\end{abstract}

Kata Kunci: TOEFL iBT, simulasi

\section{Pendahuluan}

TOEFL (Test of English as a Foreign Language) TEST merupakan salah satu jenis tes standar untuk menguji kemampuan Bahasa Inggris seseorang sebagai syarat mutlak untuk melanjutkan pendidikan ke jenjang yang lebih tinggi di hampir semua perguruan tinggi di dunia, termasuk di Indonesia. TOEFL Test umumnya diberikan oleh Educational Testing Service, atau ETS. Dewasa ini TOEFL bahkan juga digunakan untuk menguji kemampuan calon siswa SMA, untuk kenaikan jabatan, tes masuk kerja, dan lain-lain. (Silvester, 2013: 3).

Sejak 1963, TOEFL telah digunakan oleh komite seleksi beasiswa dari pemerintah, universitas, dan lembaga seperti Fulbright, Badan Pembangunan Internasional, AMIDEAST, dan Program Beasiswa Amerika Latin sebagai ukuran standar kemampuan berbahasa Inggris para kandidat. Beberapa lisensi profesional dan lembaga sertifikasi juga menggunakan skor TOEFL untuk mengevaluasi kemampuan berbahasa Inggris. Komite-komite penerimaan di lebih dari 4.500 perguruan tinggi dan universitas di Amerika Serikat, Kanada, Australia, Inggris, dan banyak negara lain di seluruh dunia mengharuskan pelamar asing untuk menyerahkan skor TOEFL bersama transkrip dan rekomendasi sebagai pertimbangan untuk diterima. (Pamela, 2013 : 16).

Pada penelitian ini dibuat suatu sistem penilaian yang ditujukan kepada pengguna untuk mengetahui prediksi tingkatan kemampuan berbahasa Inggris berdasarkan progress nilai tes TOEFL. Dikarenakan banyak aplikasi dan website terkait dengan persiapan tes TOEFL hanya memberikan nilai akhir , tanpa memberikan feedback berupa deskripsi nilai (score description) kepada pengguna.

Aplikasi ini dibuat untuk mahasiswa Politeknik Negeri Malang khususnya mahasiswa D4 Teknik Informatika, karena hanya sampai semester 4 para mahasiswa mendapatkan pelajaran Bahasa Inggris . Aplikasi ini juga dapat membantu para mahasiswa untuk melakukan persiapan tes TOEFL dengan mengerjakan soal-soal yang ada pada aplikasi dan mahasiswa juga dapat belajar secara mandiri dengan materi-materi yang telah tersedia di dalam aplikasi ini .

Untuk mengikuti TOEFL iBT dapat mendaftar secara online, di www.ets.org/toefl. Dan juga dapat mendaftar pada Pusat Registrasi wilayah di seluruh dunia (alamat tercantum di TOEFL iBT Registration and Information Bulletin). (Pamela, 2013:16)

\section{Landasan Teori}

\subsection{TOEFL}

TOEFL (Test of English as a Foreign Language) merupakan salah satu jenis tes standar untuk menguji kemampuan Bahasa Inggris 
seseorang sebagai syarat mutlak untuk melanjutkan pendidikan ke jenjang yang lebih tinggi (Silvester, 2013:3). Terkadang TOEFL merupakan sebuah persyaratan untuk orang-orang yang non-native bahasa Inggris untuk masuk ke berbagai macam lembaga, seperti instansi pemerintah, badan perizinan, bisnis, atau program beasiswa mungkin membutuhkan tes ini. Nilai TOEFL berlaku selama 2 tahun dan kemudian tidak akan lagi dilaporkan secara resmi, karena kemampuan bahasa kandidat bisa berubah signifikan sejak dia mengikuti test. Perguruan tinggi dan Universitas biasanya hanya mempertimbangkan nilai terakhir dari tes TOEFL. Tes TOEFL memiliki lisensi yang terdaftar dari Educational Testing Service (ETS) dan dikelola diseluruh dunia.

\subsection{Proses Penilaian (scoring) TOEFL \\ 2.2.1 Prosedur Penilaian}

Tes TOEFL iBT resmi memiliki bagian Reading lebih panjang dan bagian Listening lebih lama. Bagian tambahan pada setiap tes berisi pertanyaan-pertanyaan percobaan yang tidak akan dinilai sebagai bagian dari skor Anda. Anda harus melakukan yang tebaik pada semua pertanyaan karena Anda tidak akan tahu mana pertanyaan eksperimental. (Pamela, 2013: 527)

Proses penilaian (scoring) dapat dilihat pada tabel konversi berikut ini berdasarkan panduan TOEFL : For English Programs, Scoring Guides oleh ETS (Educations Testing Service) adalah sebagai berikut :

Tabel 1. Konversi Skor TOEFL

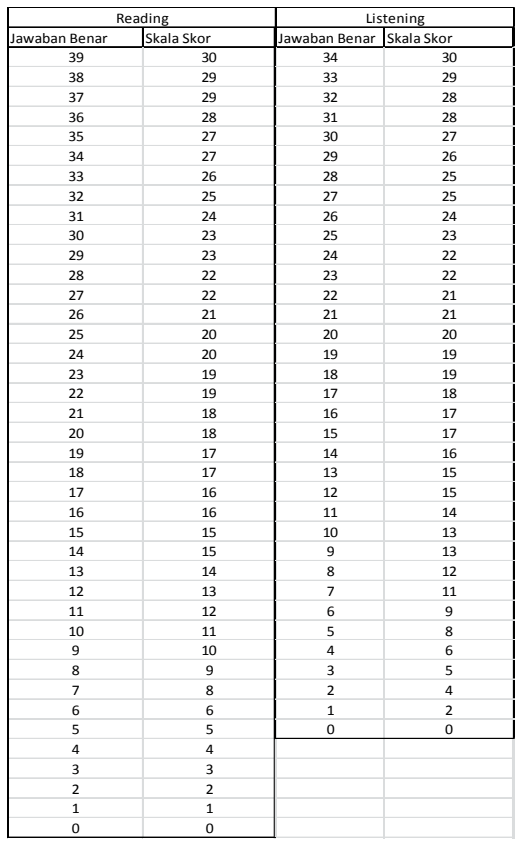

Tabel 2.Konversi Skor TOEFL (lanjutan)

\begin{tabular}{|c|c|c|c|}
\hline \multicolumn{2}{|c|}{ Speaking } & \multicolumn{2}{c|}{ Writing } \\
\hline Rentang Skala & Skala Skor & Rentang Skala & Skala Skor \\
\cline { 2 - 4 } 4.0 & 30 & 5.0 & 30 \\
\hline 3.5 & 27 & 4.5 & 28 \\
\hline 3.0 & 23 & 4.0 & 25 \\
\hline 2.5 & 19 & 3.5 & 22 \\
\hline 2.0 & 15 & 3.0 & 20 \\
\hline 1.5 & 11 & 2.5 & 17 \\
\hline 1.0 & 8 & 2.0 & 14 \\
\hline 0 & 0 & 1.5 & 11 \\
\hline & & 1.0 & 8 \\
\hline & & 0 & 0 \\
\hline
\end{tabular}

\subsection{Konsep Permodelan Sistem}

\subsubsection{WBS}

WBS (Work Breakdown Structure) merupakan gambaran struktur pembuatan sistem. WBS terdiri dari 3 (tiga) bagian yaitu Preparation, Test, Assassment. Preparation dalam sistem ini adalah memberikan data materi yang sudah disimpan oleh admin ke dalam database untuk user, meliputi tentang materi listening, materi reading, materi writing dan materi speaking . Bagian Test dalam sistem ini adalah memberikan test kepada user, meliputi test listening, test reading, test writing dan test speaking . Assessment dalam sistem ini adalah memberikan data nilai kepada user yang sudah mengerjakan ujian persiapan tes TOEFL, meliputi nilai listening, nilai reading, nilai writing dan nilai speaking. Untuk nilai speaking system penilaiannya adalah self assessment. Dimana score tidak diolah aplikasi tetapi user mengisi form checklist yang disediakan untuk mengetahui kemampuan speaking-nya.

\subsubsection{Usecase}

Rangkaian/uraian sekelompok yang saling terkait dan membentuk sistem secara teratur yang dilakukan atau diawasi oleh sebuah aktor. 'use case' digunakan untuk membentuk tingkah-laku benda/ things dalam sebuah model serta di realisasikan oleh sebuah collaboration.Umumnya 'usecase' digambarkan dengan sebuah 'elips' dengan garis yang solid, biasanya mengandung nama.

\subsection{Perangkat Lunak Yang Digunakan}

\subsubsection{MySQL}

MySQL merupakan jenis database server yang dapat mendukung pembuatan aplikasi berbasis web. $M y S Q L$ menggunakan bahasa $S Q L$ sebagai bahasa dasar untuk mengakses databasenya sehingga 
mudah digunakan, kinerja query cepat, dan mencukupi kebutuhan database perusahaanperusahaan skala menengah-kecil. Selain itu, $M y S Q L$ juga bersifat opensource sehingga tidak ada biaya yang harus dikeluarkan untuk menggunakannya.

\subsection{2 ХАMPP}

$X A M P P$ adalah perangkat lunak pengembang yang digunakan untuk pengembangan website berbasis $P H P$ dan $M y S Q L$. XAMPP dibuat dan dikembangkan oleh Apache Friends.

\section{Metode}

\subsection{Metode Penilaian}

Untuk memperoleh data hasil penilaian yang otentik (mampu menggambarkan kompetensi yang sebenarnya), pendidik dianjurkan untuk menerapkan berbagai teknik penilaian secara komplementer (saling melengkapi) sesuai dengan kompetensi yang akan dinilai. Kombinasi penggunaan berbagai teknik penilaian akan memberikan informasi yang lebih akurat tentang kemajuan belajar peserta didik.

Secara garis besar alat penilaian (evaluasi) yang digunakan dalam bidang pendidikan/pelatihan dapat digolongkan menjadi dua macam, yaitu : (1) Teknik Tes; dan (2) Teknik Bukan Tes (Non-Tes)

\section{Analisa Sistem}

\subsection{Analisis Sistem}

Tahap analisis sistem adalah tahap penguraian dari suatu sistem yang utuh ke dalam bagian-bagian komponennya dengan maksud untuk mengidentifikasikan dan mengevaluasi permasalahan-permasalahan, kesempatan kesempatan, hambatan-hambatan yang terjadi dan kebutuhan-kebutuhan yang diharapkan sehingga dapat dibuat rancangan sistem yang baru yang sesuai dengan kebutuhan.

\subsection{Analisis Permasalahan}

Suatu permasalahan tidak akan terjadi dengan sendirinya, tetapi pasti ada penyebabnya, Sistem Pembelajaran TOEFL Berbasis Web ini dibuat berdasarkan adanya permasalahan-permasalahan yang timbul adalah :

a. Bagaimana merancang dan membangun aplikasi TOEFL Preparation iBT yang menyediakan soal-soal Reading, Listening,
Speaking dan Writing dan sekaligus skor masing-masing?

\subsection{Analisis Kebutuhan}

Desain sistem yang akan dibuat memerlukan beberapa kebutuhan data masukan, kebutuhan data keluaran dan kebutuhan antar muka. Tujuan analisis kebutuhan adalah untuk menentukan spesifikasi fungsi, kemampuan serta fasilitas dari program. Analisis kebutuhan juga bermanfaat sebagai dasar evaluasi setelah program selesai disusun.

\section{Rancangan Sistem}

\subsection{WBS}

Berikut merupakan WBS untuk aplikasi TOEFL Preparation :

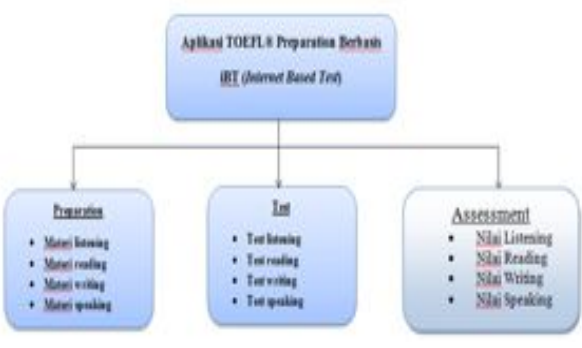

Gambar WBS

\subsection{Use Case}

Dari sisi admin :

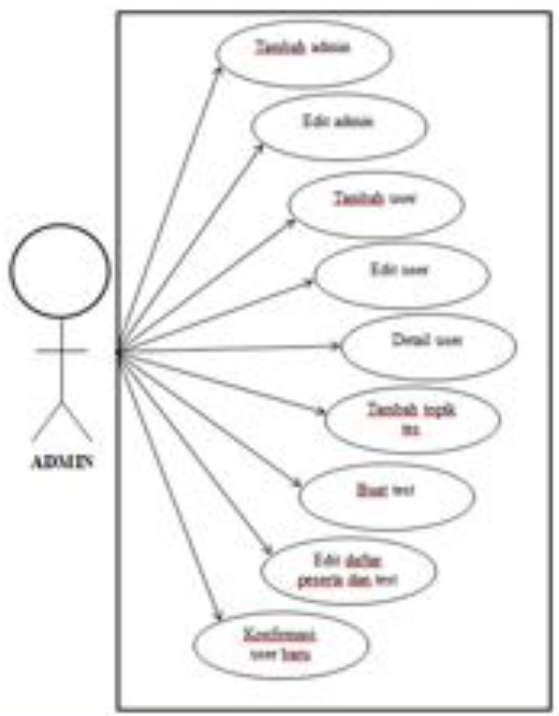


Dari sisi user :

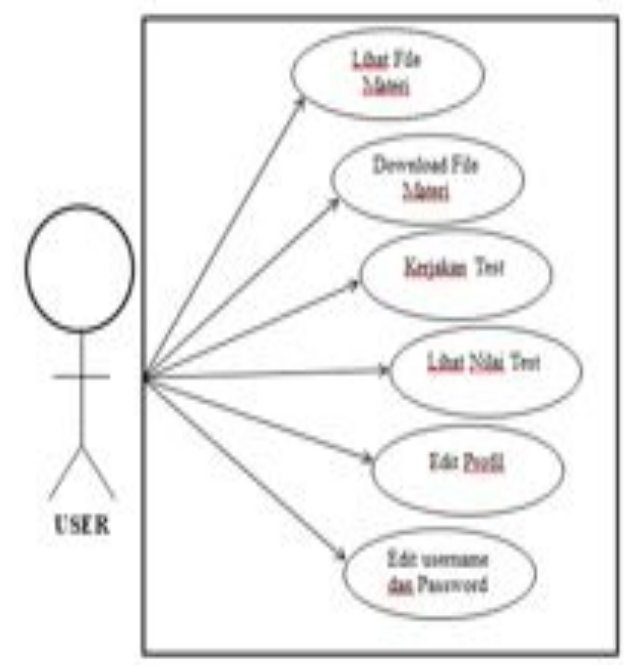

6. Implementasi

\subsection{Login Page Administrator}

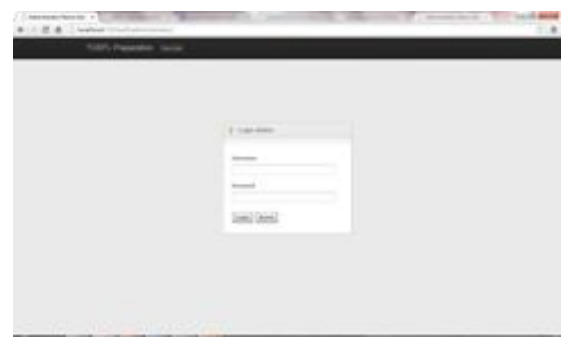

6.2

Admin Page

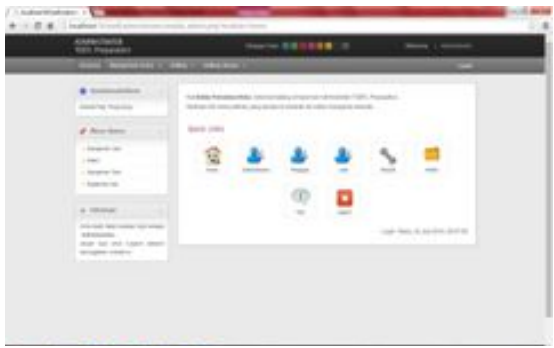

\subsection{Manajemen User}

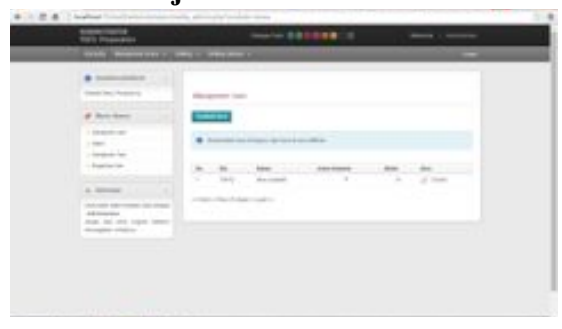

\subsection{Manajemen Test}

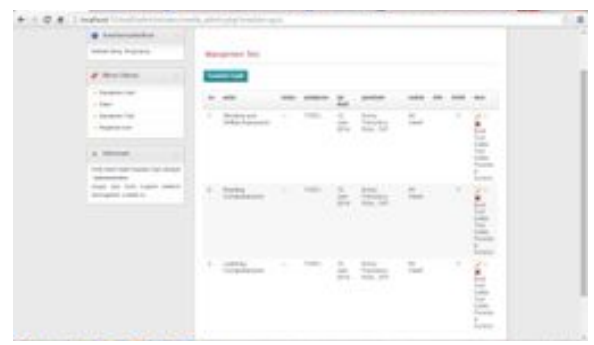

\subsection{Login Page User}

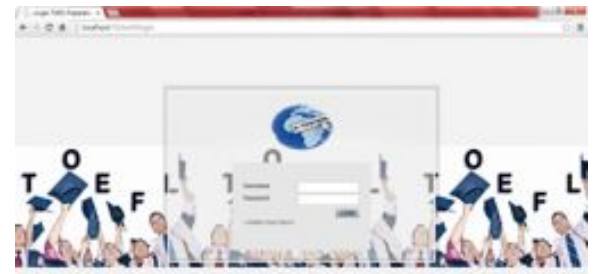

6.6 Halaman Daftar Test / Ujian

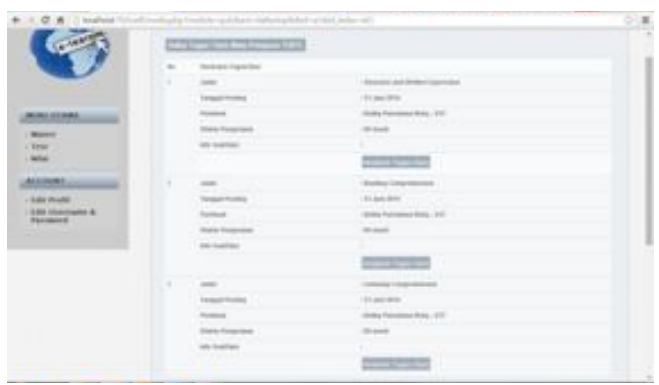

6.7 Halaman Mengerjakan Ujian / Test

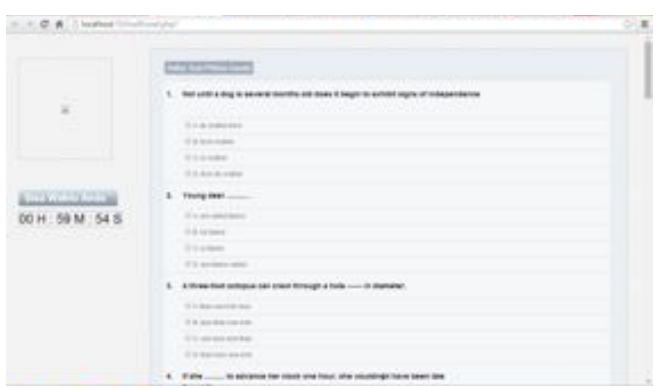

6.8 Halaman Nilai

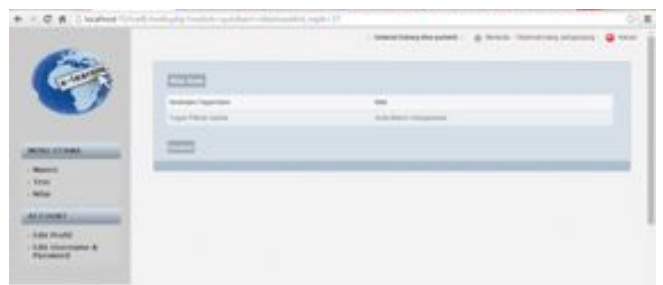




\section{Pengujian dan Analisa Hasil}

\subsection{Pengujian Fungsional}

Pada pengujian fungsional dilakukan dengan cara memberikan input pada keseluruhan modul

kemudian diperiksa hasil dari output. Jika output yang dihasilkan sesuai maka bahwa fungsi yang ada pada modul tersebut valid atau sesuai. Namun jika output yang dihasilkan tidak sesuai, maka dapat dikatakan bahwa fungsi yang ada pada modul tersebut masih terdapat error atau bug.

\section{Kesimpulan Dan Saran}

\subsection{Kesimpulan}

Berdasarkan analisa Penulis pada hasil penelitian maka dapat diambil kesimpulan, yaitu sebagai berikut:

1. Setelah diujikan menggunakan black box ,maka dapat disimpulkan bahwa aplikasi TOEFL Preparation iBT berbasis web telah berjalan sesuai dengan tujuan.

2. Setelah diujikan kepada mahasiswa (lebih dari 1 mahasiswa), maka dapat disimpulkan bahwa latihan simulasi TOEFL iBT berbasis web telah berjalan sesuai dengan tujuan.

3. Setelah diujikan kepada ahli, maka dapat disimpulkan bahwa penilaian dari setiap section ujian simulasi TOEFL iBT bernilai valid berdasarkan dengan Tabel nilai pada buku panduan TOEFL iBT.

\subsection{Saran}

Berikut adalah beberapa saran lebih lanjut mengenai skripsi ini :

1. Tampilan website dibuat lebih menarik dan lebih user friendly agar user bisa nyaman dalam mengerjakan soal-soal ujian dan mempelajari materi-materi yang telah disediakan.

2. Mamperbanyak materi-materi terkait tentang tes TOEFL iBT, baik itu dari ebook atau dari buku.

\section{Daftar Pustaka :}

Aditya, A.L. 2011, Jago PHP \& MySQL, Dunia Komputer, Jakarta.

Andi. 2006, Menguasai Pemrograman Web dengan PHP, Wahana Komputer, Semarang. Sugiri. 2007, Desain Web Menggunakan HTML + CSS, Andi Offset, Yogyakarta

Suharyanto "TSEP “(Test of Spoken English Program) Sebagai Peningkatan Mutu Kemampuan Bahasa Ingggis” Jakarta : Indonesia, 2008.

Deborah Phillips. 2006, Preparation Course For The Toefl Test: Next Generation iBT.

Pamela J.S , 2013 , Kunci Sukses TOEFL iBT, Paperplus Publisher, Tangerang. 